\title{
DAMPAK UNIVERSITY ENVIRONMENT AND SUPPORT PADA ENTREPRENEURIAL INTENTION (STUDY KASUS: MAHASISWA SEMESTER TIGA)
}

\author{
Evelyn Lawrencia Wibowo ${ }^{1}$, Sri Nathasya Br Sitepu ${ }^{2}$ \\ ${ }^{1}$ Jurusan Manajemen, Universitas Ciputra Surabaya \\ Email: elawrencia@student.ciputra.ac.id \\ ${ }^{2}$ Jurusan Manajemen, Universitas Ciputra Surabaya \\ Email: nathasya.sitepu@ciputra.ac.id
}

\begin{abstract}
This study was conducted with the aim of knowing the entrepreneurial intention of students who are directly influenced by the environment and university support and to find out the entrepreneurial intention indirectly through mediating attitudes towards behavior and self-efficacy. The sample used in the study was 80 respondents using purposive sampling technique. The respondents of this research are students who are studying in the third semester from one of the universities in East Java. The data collection process was carried out online to all respondents using the google form. The collected data was then analyzed using path analysis with the SPSS application. The results of this study indicate: 1) the environment and university support provided do not have a direct effect on the entrepreneurship intentions of third semester students, 2) Attitudes towards behavior mediate environmental influences and university support for entrepreneurship intentions of third semester students, 3) Self-efficacy mediates the influence between the environment and the environment. university support for the entrepreneurship intentions of third semester students. The contribution of this research is to provide practical input to the University to increase the entrepreneurial intention of students from the third semester until graduation.
\end{abstract}

Keywords: University Environment and Support, Attitudes to Behavior, Self-Efficacy, Entrepreneurial Intentions.

\begin{abstract}
ABSTRAK
Penelitian ini dilakukan dengan tujan untuk mengetahui entrepreneurial intention mahasiswa yang dipengaruhi secara langsung oleh lingkungan dan dukungan universitas dan mengetahui intensi berwirausaha secara tidak langsung melalui mediasi sikap terhadap perilaku dan efikasi diri. Sampel yang digunakan pada penelitian sebanyak 80 responden dengan menggunakan teknik purposive sampling. Responden penelitian ini merupakan mahasiswa yang menempuh pendidikan pada semester tiga dari salah satu Universitas di Jawa Timur. Proses pengumpulan data dilakukan secara online kepada seluruh rsponden dengan menggunakan google form. Data yang terkumpul selanjutnya dianalisis menggunakan analisis jalur dengan aplikasi SPSS. Hasil penelitian ini menunjukkan: 1) lingkungan dan dukungan universitas yang diberikan tidak berpengaruh langsung pada intensi berwirausaha mahasiswa semester tiga, 2) Sikap terhadap perilaku memediasi pengaruh lingkungan dan dukungan universitas terhadap intensi berwirausaha mahasiswa semester tiga, 3) Efikasi diri memediasi pengaruh antara lingkungan dan dukungan universitas terhadap intensi berwirausaha mahasiswa semester tiga. Kontribusi penelitian ini memberikan masukan praktisa kepada Universitas untuk meningkatkan entrepreneurial intention mahasiswa sejak semester tiga hingga lulus.
\end{abstract}

Kata Kunci: Lingkungan Dan Dukungan Universitas, Sikap Terhadap Perilaku, Efikasi Diri, Intensi Berwirausaha.

\section{PENDAHULUAN}

\section{Latar Belakang}

Penelitian ini dilakukan pada tahun 2021 pada salah satu universitas di Jawa Timur memiliki visi untuk mencetak mahasiswa menjadi seorang entrepreneur. Program studi ini memfasilitasi mahasiswa dengan kurikulum pembelajaran yang berbasis pada pendidikan entrepreneurship. pengajaran tentang bisnis dimulai sejak semester 1 dengan mata kuliah dasar-dasar kewirausahaan, semester 2 dengan mata kuliah menciptakan unit usaha, semester 3 dengan mata kuliah eksekusi bisnis, semester 4 dengan mata kuliah inovasi bisnis, semester 5 dengan mata kuliah keberlanjutan berwirausaha, semester 6 dengan mata kuliah pertumbuhan bisnis, dan semester 7 dengan mata kuliah praktek bisnis yang terintegrasi. melalui pembelajaran tersebut, 
mahasiswa diharapkan dapat mencapai tujuan capaian dari kurikulum pembelajaran. mahasiswa dituntut untuk membuat project bisnis berdasarkan ide mahasiswa yang inovatif. dengan adanya project bisnis, pembelajaran yang diberikan mengenai bisnis dapat diaplikasikan secara langsung ke dalam bisnis mahasiswa. Jumlah bisnis yang terbentuk memperlihatkan adanya intensi mahasiswa untuk berwirausaha.

University environment terdiri atas pengajaran, penelitian, dan hal lainnya yang mendukung pembelajaran seperti pengajar, organisasi kemahasiswaan, seminar, acara, dan inkubator bisnis (Moraes et al., 2018). Dalam university environment terdapat pembelajaran dan fasilitas yang dibuat untuk mengembangkan entrepreneurial intention (Laguía González et al., 2019). Demi mendukung pembelajaran, berbagai fasilitas disediakan oleh program stusi manajemen dalam menunjang pembelajarannya. Dengan university environment and support yang tersedia akan mendukung mahasiswa untuk melakukan praktik wirausaha terutama dalam project bisnis mahasiswa.

University environment and support yang diterima mahasiswa dapat membentuk attitude towards behavior dan self-efficacy mahasiswa selama menempuh pendidikan di universitas. Berdasarkan Theory of Planned Behavior (TPB), attitude towards behavior menggambarkan bagaimana seseorang menyikapi perilaku secara positif atau tidak positif (Ajzen, 1991). Dalam hal ini, mahasiswa akan menyikapi secara positif atau tidak terhadap hal kewirausahaan yang diberikan oleh universitas. Mahasiswa yang menyikapi secara positif akan memilih untuk membentuk project bisnis, sedangkan yang tidak ingin berbisnis akan memilih guild corporate entrepreneurship sebagai pembelajaran untuk bekerja pada suatu perusahaan. Self-efficacy adalah keyakinan seseorang untuk melakukan sesuatu (Bandura, 1994; Flammer, 2015). Selfefficacy mahasiswa dapat dilihat dengan bagaimana mahasiswa yakin akan bisnis yang mereka jalankan. Mahasiswa akan memperkenalkan bisnisnya kepada masyarakat melalui bazar, atau mengikuti pameran yang dilibatkan oleh kampus seperti Trade Expo Indonesia dan SIAL Interfood. Dengan demikian, entrepreneurial intention mahasiswa dapat terbentuk melalui university environment and support, attitude towards behavior, dan self-efficacy.

Hubungan university environment, entrepreneurial intention melalui self-efficacy diterima oleh mahasiswa semester tiga. University environment dalam bentuk pembelajaran teori, seminar bisnis, bantuan dari inkubator, ketersediaan organisasi kemahasiswaan dibentuk dengan tujuan meningkatkan self-efficacy. Mahasiswa semester tiga sudah menerima teori/konsep serta mengikuti seminar bisnis dari pengusaha/praktisi yang hadir sebagai pembicara. Pengalaman pembicara seminar dapat dijadikan bekal untuk mendirikan bisnis. Eksekusi bisnis mahasiswa semester tiga didampingi oleh incubator sehingga meningkatkan self-efficacy mahasiswa dalam menjalankaan bisnis. Kondisi mahasiswa dengan self-efficacy yang tinggi akan meningkatkan entrepreneurial intention. Mahasiswa diharapkan mengembangkan bisnis hingga lulus dari universitas dan menciptakan lapangan kerja. Kombinasi teori dan praktek bisnis mampu meningkatkan keterampilan mahasiswa ketika mengelola bisnis ( $\mathrm{Br}$ Sitepu, 2017).

\section{Rumusan Masalah}

Semakin banyak jumlah bisnis yang terbentuk, artinya terdapat entrepreneurial intention yang dimiliki oleh mahasiswa. Mahasiswa semester tiga sudah mendapatkan pendidikan entrepreneurship dasar dan mulai melakukan praktik bisnis selama 1 tahun. Sejak awal mahasiswa dibentuk menjadi seorang entrepreneur sehingga penting untuk melihat kondisi intensi berwirausaha. Berdasarkan latar belakang, peneliti ingin melihat dampak university environment and support pada entrepreneurial intention pada mahasiswa semester tiga.

\section{METODE PENELITIAN}


Metode kuantitatif digunakan pada penelitian ini dimana, populasinya adalah mahasiswa yang berada pada semester tiga. Teknik purposive sampling digunakan dalam pemilihan sampel yang dilengkapi dengan beberapa kriteria tertentu sesuai tujuan penelitian (Thohir, 2013). Responden harus memenuhi kriteria sampel berikut:

1) Mahasiswa jurusan manajemen semester tiga.

2) Mahasiswa mengambil mata kuliah Entrepreneurial Venture Execution.

Penentuan jumlah sampel penelitian didasarkan pada (Hair et al., 1999; Trivedi, 2016) untuk dapat mewakili populasi penelitian yaitu dengan minimal 5 responden dari setiap variabel dan jumlah yang diinginkan sebanyak 15 hingga 20 responden pada setiap variabel. Penelitian ini terdiri dari 1 variabel independen, 2 variabel intervensi, dan 1 variabel dependen. Tabel 1 merupakan perhitungan jumlah sampel penelitian:

Tabel 1. Perhitungan Jumlah Sampel Penelitian

\begin{tabular}{cc}
\hline Responden & Perhitungan \\
\hline Semester Tiga & $(20 \times 1)+(20 \times 2)+(20 \times 1)=20+40+20=80$ \\
\hline
\end{tabular}

Sampel penelitian sebanyak 80 mahasiswa semester tiga yang menjadi responden penelitian dimana, seluruh rsponden teah sesuai dengan kriteria penelitian. Data penelitian diperoleh dari google form yang disebarkan secara online kepada responden penelitian.

Penelitian ini juga melakukan pengujian instrument menggunakan uji validitas dengan tujuan melihat valid atau tidak dari keseluruhan item pernyataan pada quisioner. Item pernyataan quisioner dinyatakan valid ketika perolehan nilai $\mathrm{r}$ atau corrected item total correlation hitung jika lebih besar dari nilai total correlation tabel (Sujarweni \& Utami, 2019). Penelitian juga akan menguji konsistensi dari jawaban responden pada variabel penelitian dengan uji reliabilitas. Pernyataan kuisioner dinyatak reliabel jika perolehan nilai cronbach's alpha lebih besar dari 0,70 (Sujarweni \& Utami, 2019).

Data dianalisis dengan path analysis pada aplikasi SPSS. Path analysis nantinya akan menjelaskan hubungan sebab akibat berdasarkan pengaruh langsung dan pengaruh tidak langsung dari variable bebas terhadap variable terikat (Sarwono, 2014). Persamaan analisis jalur dilihat pada gambar 1 .

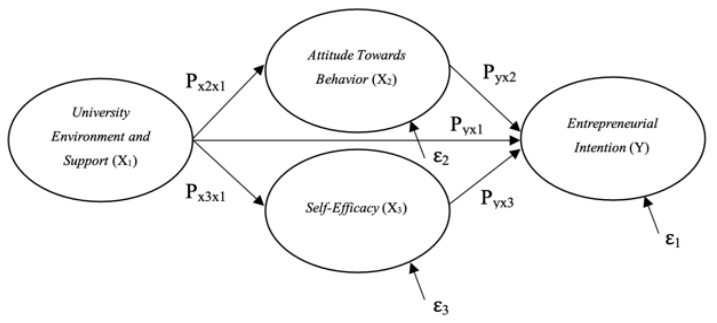

Gambar 1. Persamaan Analisis Jalur

Pengaruh langsung

$\mathrm{Y}=\mathrm{P}_{\mathrm{yx} 1} \cdot \mathrm{X}_{1}+\varepsilon_{1}$

Pengaruh tidak langsung

$\mathrm{Y}=\mathrm{P}_{\mathrm{yx} 2} \cdot \mathrm{X}_{2}+\mathrm{P}_{\mathrm{x} 2 \mathrm{x} 1} \cdot \mathrm{X}_{1+\varepsilon_{2}}$

$\mathrm{Y}=\mathrm{P}_{\mathrm{yx} 3} \cdot \mathrm{X}_{3}+\mathrm{P}_{\mathrm{x} 3 \mathrm{x} 1} \cdot \mathrm{X}_{1+} \varepsilon_{3}$

Keterangan: 
$\mathrm{X}_{1} \quad$ : Variabel Independen

$\mathrm{X}_{2} \quad$ : Variabel Intervensi

$\mathrm{X}_{3} \quad$ : Variabel Intervensi

Y : Variabel Dependen

$\mathrm{P}_{\mathrm{x} 2 \mathrm{x} 1}$ : Pengaruh $\mathrm{X}_{1}$ terhadap $\mathrm{X}_{2}$

$\mathrm{P}_{\mathrm{x} 3 \mathrm{x} 1}$ : Pengaruh $\mathrm{X}_{1}$ terhadap $\mathrm{X}_{3}$

$\mathrm{P}_{\mathrm{yx} 1} \quad$ : Pengaruh $\mathrm{X}_{1}$ terhadap $\mathrm{Y}$

$\mathrm{P}_{\mathrm{yx} 2}$ : Pengaruh $\mathrm{X}_{2}$ terhadap $\mathrm{Y}$

$\mathrm{P}_{\mathrm{yx} 3}$ : Pengaruh $\mathrm{X}_{3}$ terhadap $\mathrm{Y}$

$\varepsilon_{1}, \varepsilon_{2}, \varepsilon_{3}:$ Error

Analisis jalur yang menggunakan analisis regresi yang bertujuan untuk melihat pengaruh variabel independen terhadap dependen dan hasilnya akan digunakan dalam perhitungan analisis jalur harus memenuhi syarat uji $\mathrm{F}$, uji t, uji multikoliniertitas, uji normalitas, dan uji heteroskedastisitas (Sarwono, 2014).

\section{HASIL DAN PEMBAHASAN} Analisis Regresi dan Analisis Jalur

Tabel 2. Hasil Analisis Regresi Mahasiswa Semester tiga

\begin{tabular}{|c|c|c|c|c|c|}
\hline & Regresi & Model & $\begin{array}{c}\text { Variabel } \\
\text { Dependen }\end{array}$ & $\begin{array}{l}\text { Nilai } \\
\text { Beta }\end{array}$ & R Square \\
\hline \multicolumn{6}{|c|}{ Pengaruh Langsung } \\
\hline \multirow{3}{*}{ I } & \multirow{3}{*}{$\begin{array}{c}\mathrm{UES}+\mathrm{ATB}+ \\
\mathrm{SE} \rightarrow \mathrm{EI}\end{array}$} & UES & \multirow{3}{*}{ EI } & $-0,026$ & \multirow{3}{*}{0,685} \\
\hline & & ATB & & 0,673 & \\
\hline & & SE & & 0,209 & \\
\hline \multicolumn{6}{|c|}{ Pengaruh Tidak Langsung } \\
\hline II & $\mathrm{UES} \rightarrow \mathrm{ATB}$ & UES & ATB & 0,581 & 0,337 \\
\hline $\begin{array}{c}\text { II } \\
\text { I }\end{array}$ & $\mathrm{UES} \rightarrow \mathrm{SE}$ & UES & SE & 0,551 & 0,303 \\
\hline
\end{tabular}

Hasil analisis regresi yang dilakukan pada kelompok responden mahasiswa semester tiga menunjukkan nilai $\mathrm{R}$ square regresi I sebesar 68,5\% merupakan pengaruh dari university environment and support, attitude towards behavior, dan self-efficacy. Artinya terdapat sebanyak $31,5 \%$ yang merupakan pengaruh dari variabel lain selain variabel yang diteliti. Nilai $\mathrm{R}$ square regresi II adalah 33,7\%. Nilai ini menunjukkan besarnya pengaruh yang diberikan oleh variabel university environment and support terhadap attitude towards behavior yang berarti terdapat $66,3 \%$ faktor lain selain university environment and support. Hasil R square pada regresi III adalah 30,3\% pengaruh dari university environment and support terhadap self-efficacy, berarti terdapat $69,7 \%$ sisanya yang merupakan dampak variabel lain di luar penelitian.

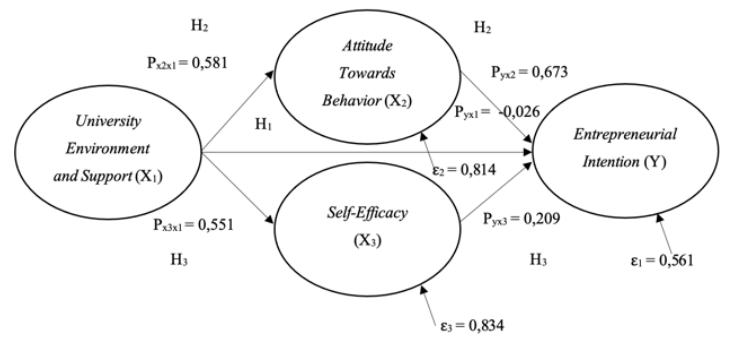

Gambar 2. Analisis Jalur Mahasiswa Semester Tiga 


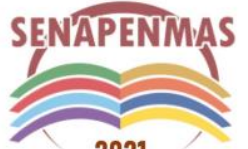

2021

Pengaruh langsung

$\mathrm{Y}=\mathrm{P}_{\mathrm{yx} 1} \cdot \mathrm{X}_{1}+\varepsilon_{1}=-0,026 \cdot \mathrm{X}_{1}+0,561$

Pengaruh tidak langsung

$\mathrm{Y}=\mathrm{P}_{\mathrm{yx} 2} \cdot \mathrm{X}_{2}+\mathrm{P}_{\mathrm{x} 2 \mathrm{x} 1} \cdot \mathrm{X}_{1}+\varepsilon_{2}=0,673 \cdot \mathrm{X}_{2}+0,581 \cdot \mathrm{X}_{1}+0,814$

$\mathrm{Y}=\mathrm{P}_{\mathrm{yx} 3} \cdot \mathrm{X}_{3}+\mathrm{P}_{\mathrm{x} 3 \mathrm{x} 1} \cdot \mathrm{X}_{1+\varepsilon_{3}}=0,209 \cdot \mathrm{X}_{3}+0,551 \cdot \mathrm{X}_{1}+0,834$

Hasil uji F menunjukkan bahwa nilai signifikansi model regresi I, II, dan III dengan nilai 0,000 lebih kecil dari 0,05 sehingga dapat disimpulkan telah memenuhi syarat uji $\mathrm{F}$ (goodness of fit test).

Tabel 3. Uji t Mahasiswa Semester Tiga

\begin{tabular}{ccccc}
\hline Regresi & $\begin{array}{c}\text { Variabel } \\
\text { Independen }\end{array}$ & $\begin{array}{c}\text { Variabel } \\
\text { Dependen }\end{array}$ & Sig \\
\hline \multirow{2}{*}{ I } & $\mathrm{X}_{1}$ & & 0,748 \\
\cline { 2 - 2 } & $\mathrm{X}_{2}$ & $\mathrm{Y}$ & 0,000 \\
\cline { 2 - 4 } & $\mathrm{X}_{3}$ & & 0,043 \\
\hline II & $\mathrm{X}_{1}$ & $\mathrm{X}_{2}$ & 0,000 \\
\hline III & $\mathrm{X}_{1}$ & $\mathrm{X}_{3}$ & 0,000 \\
\hline
\end{tabular}

Nilai sig 0,748 lebih besar dari 0,05 pada tabel 2 menujukkan pengaruh university environment and support terhadap entrepreneurial intention. Interpretasi nilai sig tersebut bermakna pengaruh university environment and support terhadap entrepreneurial intention tidak berhasil memenuhi kriteria uji t. Nilai sig yang lebih kecil dari 0,05 yang berarti model regresi I (attitude towards behaviour terhadap entrepreneurial intention dan self-efficacy terhadap entrepreneurial intention), model II (university environment and support terhadap attitude towards behaviour) dan model III (university environment and support terhadap self-efficacy) sudah memenuhi kriteria uji t. Kesimpulan dari model regresi I ditemukan university environment and support $\left(\mathrm{X}_{1}\right)$ tidak berpengaruh terhadap entrepreneurial intention $(\mathrm{Y})$. Masih pada model regresi I ditemukan pengaruh yang signifikan dari variabel attitude towards behavior $\left(\mathrm{X}_{2}\right)$ terhadap entrepreneurial intention $(\mathrm{Y})$ dan self-efficacy $\left(\mathrm{X}_{3}\right)$ terhadap entrepreneurial intention $(\mathrm{Y})$. Hasil analisis dari model regresi II terdapat pengaruh signifikan university environment and support $\left(\mathrm{X}_{1}\right)$ terhadap attitude towards behavior $\left(\mathrm{X}_{2}\right)$. Analisis dari model III juga terdapat pengaruh yang signifikan dari university environment and support $\left(\mathrm{X}_{1}\right)$ terhadap self-efficacy $\left(\mathrm{X}_{3}\right)$.

Tabel 4. Pengaruh Langsung dan Tidak Langsung Mahasiswa Semester Tiga

\begin{tabular}{cccccc}
\hline $\begin{array}{c}\text { Regr } \\
\text { esi }\end{array}$ & Pengaruh & $\begin{array}{c}\text { Direct } \\
\text { Effect }\end{array}$ & \multicolumn{2}{c}{ Indirect Effect } & Total Effect \\
\hline \multirow{3}{*}{$\mathrm{I}$} & $\mathrm{X}_{1} \rightarrow \mathrm{Y}$ & $-0,026$ & ${\text { Melalui } \mathrm{X}_{2}}$ & 0,391013 & 0,365013 \\
\cline { 2 - 7 } & $\mathrm{X}_{2} \rightarrow \mathrm{Y}$ & 0,673 & Melalui $\mathrm{X}_{3}$ & 0,115159 & 0,089159 \\
\cline { 2 - 6 } & $\mathrm{X}_{3} \rightarrow \mathrm{Y}$ & 0,209 & - & - & - \\
\hline II & $\mathrm{X}_{1} \rightarrow \mathrm{X}_{2}$ & 0,581 & - & - & - \\
\hline III & $\mathrm{X}_{1} \rightarrow \mathrm{X}_{3}$ & 0,551 & - & - & - \\
\hline
\end{tabular}

Tabel di atas menunjukkan hasil analisis pengaruh langsung dan tidak langsung pada mahasiswa semester tiga yang dijelaskan sebagai berikut:

1. Pengaruh langsung $X_{1}$ terhadap $Y$

$\mathrm{Y}=\mathrm{P}_{\mathrm{yx} 1}=-0,026$ 
Nilai pengaruh langsung $X_{1}$ terhadap $Y$ sebesar -0,026. Nilai ini menunjukkan university environment and support $\left(\mathrm{X}_{1}\right)$ tidak berpengaruh terhadap entrepreneurial intention $(\mathrm{Y})$.

2. Pengaruh $\mathrm{X}_{1}$ terhadap $\mathrm{Y}$ melalui $\mathrm{X}_{2}$

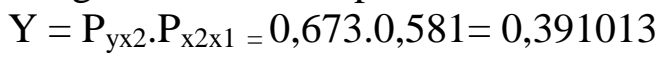

Pengaruh total $=-0,026+0,391013=0,365013$

Nilai pengaruh tidak langsung $X_{1}$ terhadap $Y$ melalui $X_{2}$ sebesar 0,391013. Nilai pengaruh langsung $\mathrm{X}_{1}$ terhadap $\mathrm{Y}$ sebesar $-0,026$. Hal ini menunjukkan nilai pengaruh tidak langsung lebih besar dibandingkan nilai pengaruh langsungnya. Sehingga dapat disimpulkan bahwa attitude towards behavior memediasi pengaruh university environment and support terhadap entrepreneurial intention.

3. Pengaruh $\mathrm{X}_{1}$ terhadap $\mathrm{Y}$ melalui $\mathrm{X}_{3}$

$\mathrm{Y}=\mathrm{P}_{\mathrm{yx} 3 .} \cdot \mathrm{P}_{\mathrm{x} 3 \mathrm{x} 1}=0,209 \cdot 0,551=0,115159$

Pengaruh total $=-0,026+0,115159=0,089159$

Nilai pengaruh tidak langsung $X_{1}$ terhadap $Y$ melalui $X_{3}$ sebesar 0,115159 . Nilai. Nilai pengaruh langsung $\mathrm{X}_{1}$ terhadap $\mathrm{Y}$ sebesar -0,026. Hal ini menunjukkan nilai pengaruh tidak langsung lebih besar dibandingkan dengan nilai pengaruh langsung. Sehingga dapat disimpulkan bahwa self-efficacy memediasi pengaruh university environment and support terhadap entrepreneurial intention.

Tabel 5 merupakan kesimpulan hipotesis penelitian berdasarkan hasil analisis statistik dari seluruh data responden (mahsiswa semester tiga) sebagai berikut:

Tabel 5. Hasil Pengujian Hipotesis Mahasiswa Semester Tiga

\begin{tabular}{cc}
\hline Hipotesis & Hasil \\
\hline $\mathrm{H}_{1}$ & Ditolak \\
\hline $\mathrm{H}_{2}$ & Diterima \\
\hline $\mathrm{H}_{3}$ & Diterima \\
\hline
\end{tabular}

\section{Uji Asumsi Klasik}

\section{Uji Multikolinieritas}

Perolehan nilai analisis VIF menghasilkan nilai yang berkisar antara 1-10. Perolehan nilai itu muncul pada model regresi I, II dan model regresi III. Interpretasi dari nilai VIF pada keseluruhan model terbebas dari multikolinieritas.

Tabel 6. Hasil Uji Multikolinieritas

Coefficients $^{\mathrm{a}}$

\begin{tabular}{|c|c|c|c|c|c|c|c|c|}
\hline \multirow[b]{2}{*}{ Mode } & & \multicolumn{2}{|c|}{ Unstandardized Coefficients } & \multirow{2}{*}{$\begin{array}{c}\text { Standardized } \\
\text { Coefficients } \\
\text { Beta }\end{array}$} & \multirow[b]{2}{*}{$\mathrm{t}$} & \multirow[b]{2}{*}{ Sig. } & \multicolumn{2}{|c|}{ Collinearity Statistics } \\
\hline & & B & Std. Error & & & & Tolerance & VIF \\
\hline \multirow[t]{4}{*}{1} & (Constant) & 3.008 & 2.609 & & 1.153 & .253 & & \\
\hline & $\begin{array}{l}\text { University Environment } \\
\text { and Support }\end{array}$ & -.022 & .067 & -.026 & -.322 & .748 & .635 & 1.576 \\
\hline & $\begin{array}{l}\text { Attitude Towards } \\
\text { Behavior }\end{array}$ & .747 & .115 & .673 & 6.481 & .000 & .385 & 2.601 \\
\hline & Self-efficacy & .223 & .108 & .209 & 2.063 & .043 & .404 & 2.474 \\
\hline
\end{tabular}

a. Dependent Variable: Entrepreneurial Intention

\section{Uji Normalitas}

Seluruh model regresi pada setiap kelompok responden menunjukkan grafik histogram dengan pola membentuk kurva lonceng. Gambar pada P-P Plot menghasilkan penyebaran titik-titik berada dekat di sekitar garis diagonal. Interpretasi dari sebaran titik dalam grafik P-P Plot menjelaskan model regresi I-III keseluruhan kelompok responden terdistribusi normal. 


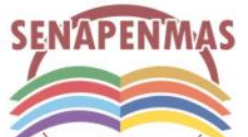

2021

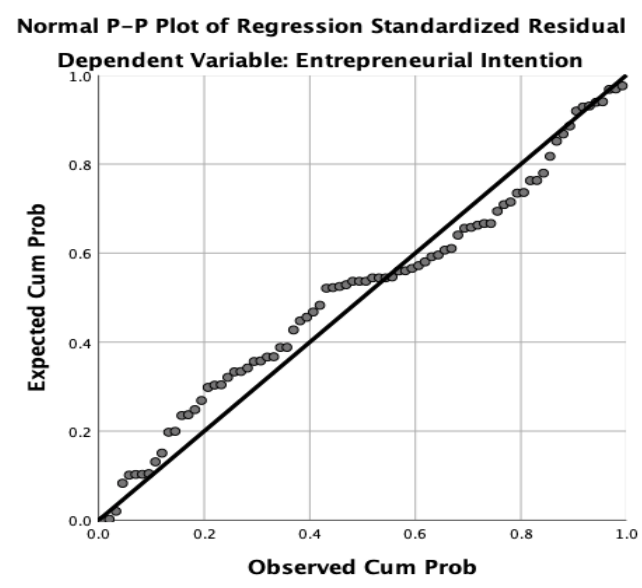

Gambar 3. Grafik P-P Plot

\section{Uji Heteroskedastisitas}

Hasil analisis pada uji heteroskedastisitas ditunjukkan dengan gambar scatterplot. Sebaran titik pada scatterplot pada sumbu Y disebaran atas dan bagian bawah angka 0 dimana, tidak ada pola tertentu. Seluruh model I, II hingga model III untuk seluruh kelompok responden dinyatakan bebas dari heteroskedastisitas.

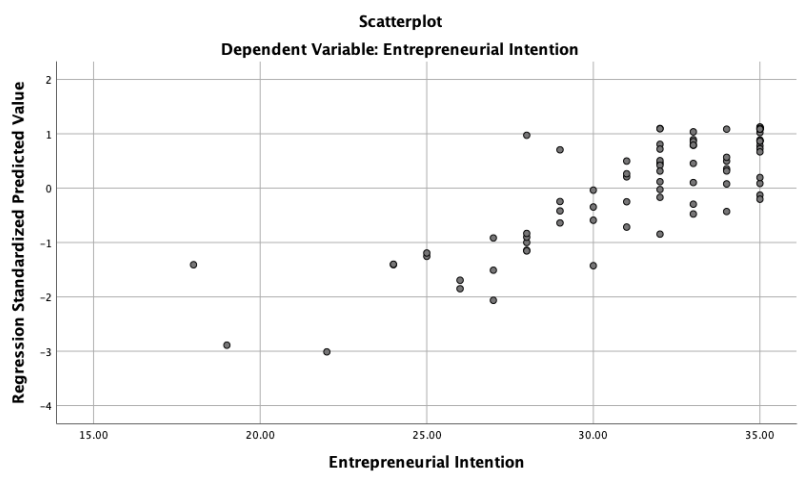

Gambar 4. scatterplot

\section{Pembahasan}

Dampak Langsung University Environment and Support pada Entrepreneurial Intention Mahasiswa Semester Tiga

Hasil peneiltian pada mahasiswa semester tiga menunjukkan $\mathrm{H}_{1}$ ditolak. Hasil pada penelitian ini didukung oleh penelitian terdahulu (Nowiński et al., 2019) yang menyatakan entrepreneurship education tidak berpengaruh terhadap entrepreneurial intention. Artinya entrepreneurial intention mahasiswa semester tiga tidak dipengaruhi oleh university environment and support. Hipotesis yang ditolak menunjukkan kurangnya dukungan non kognitif yang diberikan oleh universitas kepada mahasiswa semester tiga. Mahasiswa semester tiga berada melakukan eksekusi bisnis membutuhkan modal awal untuk melakukan pengoperasian bisnis seperti biaya produksi. Akan tetapi, mahasiswa tidak mendapatkan bantuan dana untuk modal bisnisnya. Hal ini menjadi kendala bagi mahasiswa tiga untuk merintis bisnisnya tersebut. Mahasiswa semester tiga belum mendapatkan akses untuk mengikuti kegiatan pameran khususnya pameran di luar Surabaya seperti Trade Expo Indonesia dan SIAL Interfood. Mahasiswa semester tiga juga merasa kurangnya fasilitas untuk melakukan pameran yang berskala internal yang hanya terbatas pada area lobby Plaza kampus. Kondisi yang dialami mahasiswa semester tiga menyebabkan 
variabel university environment and support tidak memengaruhi intensi berwirausaha mereka secara langsung.

\section{Dampak University Environment and Support Pada Entrepreneurial Intention Melalui Attitude Towards Behavior Mahasiswa Semester Tiga}

Hasil analisis $\mathrm{H}_{2}$ diterima pada responden (mahasiswa semester tiga). Temuan penelitian ini sejalan dengan penelitian oleh (Soria-Barreto et al., 2017; Surya dan Sitepu., 2019) dengan temuan sebelumnya dimana, university environment and support telah memengaruhi entrepreneurial intention dengan menggunakan variabel attitude towards behaviour sebagai variable mediasi. Interpretasi dari hipotesis yang diterima bermakna bahwa entrepreneurial intention responden (mahasiswa semester tiga) secara tidak langsung dipengaruhi oleh university environment and support melalui attitude towards behavior.

Penelitian ini menunjukkan bahwa mahasiswa semester tiga menilai bisnis secara positif yang ditunjukkan dengan tingginya ketertarikan mahasiswa akan peluang usaha. Sikap positif yang ditunjukkan ini memberikan dampak yang tinggi pada intensinya untuk melakukan bisnis. Keinginan mahasiswa semester tiga untuk melakukan bisnis akan muncul jika mereka memiliki sumber daya dan adanya peluang. Sehingga dapat dilihat mahasiswa yang berada pada lingkungan universitas yang berbasis entrepreneurship dapat memengaruhi sikap mahasiswa terhadap hal bisnis, terutama jika motivasi untuk berbisnis sering diberikan kepada mahasiswa. Apabila universitas memberikan dukungan berupa sumber daya berupa pendanaan kepada mahasiswa, ini akan meningkatkan intensi mahasiswa untuk merintis bisnisnya. Hal ini dikarenakan keterbatasan sumber daya (pendanaan). Sikap positif yang ditunjukkan mahasiswa semester tiga memutuskan pilihan kariernya adalah menjadi seorang entrepreneur.

\section{Dampak University Environment and Support Pada Entrepreneurial Intention Melalui Self-} Efficacy Mahasiswa Semester Tiga

Hasil analisis menemukan $\mathrm{H}_{3}$ diterima pada responden (mahasiswa semester tiga). Hipotesis $\mathrm{H}_{3}$ yang diterima ini sejalan dengan penelitian (Moraes et al., 2018; Trivedi, 2016: Li, 2020) dimana temuan sebelumnya mendapatkan variable self-efficacy memediasi pengaruh antara university environment and support dan entrepreneurial intention.

Self-efficacy (Efikasi diri) dari mahasiswa pada semester tiga ditunjukkan melalui tingkat keyakinan mahasiswa untuk membentuk sebuah bisnis. Keyakinan dalam diri mahasiswa dapat terbentuk melalui dorongan motivasi yang diberikan oleh universitas yang biasanya bisa didapatkan dari kuliah tamu oleh pengusaha sukses, mentor bisnis, dan juga pengajar pada saat belajar mengajar. Selain itu, mahasiswa semester tiga juga memiliki keyakinan akan kemampuannya sendiri untuk melaksanakan suatu tugas tertentu. Kemampuan tersebut berupa kemampuan merencanakan dan mengembangkan ide bisnis. Mahasiswa semester tiga memiliki keyakinan ini dikarenakan mereka telah menjalani tahap bisnis pada semester dua hingga semester tiga yang difokuskan pada pengembangan ide bisnis mahasiswa dan melakukan perencanaan atas ide yang diusulkan.

\section{KESIMPULAN DAN SARAN}

Kesimpulan

Hasil penelitian entrepreneurial intentions pada mahasiswa semester tiga diantaranya:

1. Entrepreneurship education tidak berpengaruh terhadap entrepreneurial intention mahasiswa semester tiga.

2. University environment and support memengaruhi entrepreneurial intention melalui mediasi attitude towards behaviour pada mahasiswa semester tiga. 


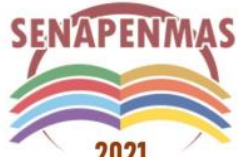

2021

Seminar Nasional Hasil Penelitian dan Pengabdian Kepada Masyarakat 2021

Pengembangan Ekonomi Bangsa Melalui Inovasi Digital Hasil Penelitian dan Pengabdian Kepada Masyarakat Jakarta, 21 Oktober 2021

3. Self-efficacy memediasi pengaruh antara university environment and support dan entrepreneurial intention pada mahasiswa semester tiga.

\section{Saran}

Universitas perlu memberikan dukungan pendanaan, dan menyediakan sarana dan prasarana yang mendukung mahasiswa untuk mengembangkan bisnisnya. Universitas diharapkan terus memotivasi mahasiswa untuk melakukan bisnis. Universitas meperbanyak kuliah tamu dan seminar yang dapat membentuk kemampuan mahasiswa. Bagi penelitian selanjutnya dapat diperluas dengan meneliti faktor lain yang dapat memengaruhi entrepreneurial intention.

\section{Ucapan Terima Kasih}

Saya mengucapkan terima kasih kepada pihak yang membantu penelitian ini diantaranya:

1. Rektor Universitas Swasta di Jawa Timur

2. Responden (mahasiswa semester tiga)

3. Tim peneliti entrepreneurship

\section{REFERENSI}

Ajzen, I. (1991). The Theory of Planned Behavior Organizational Behavior and Human Decision Processes. Organizational Behavior and Human Decision Processes, 50(2), 179211.

Br Sitepu, S. N. (2017). Pendekatan Entrepreneurial Individual untuk Menciptakan Behaviours Entrepreneurship Studi Kasus Mahasiswa Universitas Ciputra Surabaya.

Flammer, A. (2015). Self-Efficacy. International Encyclopedia of the Social \& Behavioral Sciences: Second Edition, 4(1994), 504-508. https://doi.org/10.1016/B978-0-08-0970868.25033-2

Laguía González, A., Jaén, I., Topa, G., \& Moriano, J. (2019). University environment and entrepreneurial intention: the mediating role of the components of the theory of planned behaviour / El entorno universitario y la intención emprendedora: el papel mediador de los componentes de la teoría de la acción planificad. Revista de Psicologia Social, 34(1), 137167. https://doi.org/10.1080/02134748.2018.1542789

Li, C. (2020). Self-efficacy theory. Routledge Handbook of Adapted Physical Education, 313325. https://doi.org/10.4324/9780429052675-24

Moraes, G. H. S. M. de, Iizuka, E. S., \& Pedro, M. (2018). Effects of Entrepreneurial Characteristics and University Environment on Entrepreneurial Intention. Revista de Administração Contemporânea, 22(2), 226-248. https://doi.org/10.1590/19827849rac2018170133

Nowiński, W., Haddoud, M. Y., Lančarič, D., Egerová, D., \& Czeglédi, C. (2019). The impact of entrepreneurship education, entrepreneurial self-efficacy and gender on entrepreneurial intentions of university students in the Visegrad countries. Studies in Higher Education, 44(2), 361-379. https://doi.org/10.1080/03075079.2017.1365359

Sarwono, J. (2014). Path analysis dengan SPSS. Elex Media Komputindo.

Soria-Barreto, K., Honores-Marin, G., Gutiérrez-Zepeda, P., \& Gutiérrez-Rodríguez, J. (2017). Prior exposure and educational environment towards entrepreneurial intention. Journal of Technology Management and Innovation, 12(2), 45-58. https://doi.org/10.4067/S071827242017000200006

Sujarweni, V. W., \& Utami, L. R. (2019). The Master Book of SPSS. Anak Hebat Indonesia.

Surya, J. E., Nathasya, S., \& Sitepu, B. (2019). Pengaruh University Environment And Support

Terhadap Entrepreneurial Intention Generasi Milenial Mengembangkan UMKM. 1(20), $19-27$.

Thohir, M. (2013). Metodologi Penelitian Sosial Budaya (2nd ed.). Bumi Aksara. 
https://difarepositories.uin-suka.ac.id/152/1/metodologi penelitian sosial.pdf

Trivedi, R. (2016). Does university play significant role in shaping entrepreneurial intention? A cross-country comparative analysis. In Journal of Small Business and Enterprise Development (Vol. 23, Issue 3). https://doi.org/10.1108/JSBED-10-2015-0149 